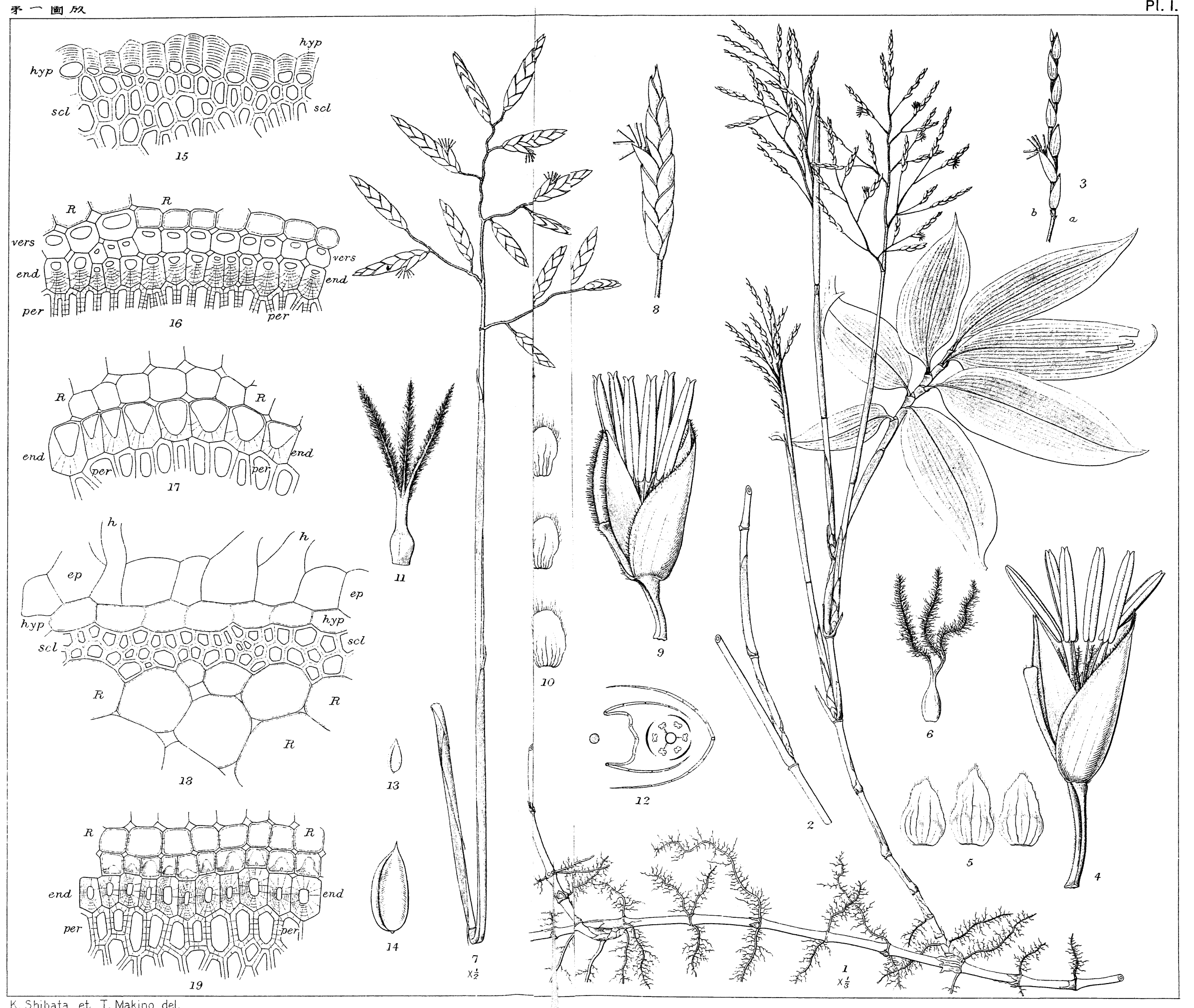




\section{On Sasa, a New Genus of Bambuseæ, and its Affinities.}

By

T. Makino AND K. Shibata.

With Plate I.

As is well known a number of indigenous sprecies of bambon-plants have been recorded from Japan as belonging to the genus Bambusa, as for examples, B. senanensis Fr. et Sav., B. palmota Marliac, B. Veitchii Carr., P. borealis Hack. etc. 'These plants were referred to this genus according to their possession of six stamens, which character having been hitherto regarded as of great systematic importance for the Bambuser. Yet a closer examination of these species with regard to their external as well as to internal structures renders it very difficult to acknowledge their position in the genus Bambusa, and we have been convinced that they should be reasonably separated from Bambusa and erected into a new genus, for which we propose the name Sasa." 'The genus may be briefly diagnosed as follows :-

Sasa, gen. nov.

(Arundinaria sect. Bambusoides, Shibata et Makino, in Bamb. Jap. in Bot. Mag., Tokyo, XIV, p. 20 ; Bambusa auct. partim.)

Spicula 4-13-flowered, narrow, more or less compressed; rachilla articulated. Flowers closely or laxly disposed on the rachilla, lanceolate, hermaphrodite but the terminal one imperfect. Empty glumes 2, small, unequal, membranaceous, closely approximate or sometimes a little remote, the inferior one often very minute. Flowering glume much larger than the empty glumes, chartaceous or membranaceous, ecarinate, many nerved, sharply pointed at the apex. Pallea usually very slightly shorter or rarely longer than the flowering glume, distinctly bicarinate, usually bifid at the apex, membranaceous. Lodicule 3. Stamens 6 (rarely fewer), exserted ; filaments free. Ovary glabrous; styles short, connate below or nearly connate into one; stigmas

1) "Sasa" is the common Japanese name signifying "small bamboos" and has already heen used by Siebold in an analogous sense in his Syn. Pl. Oecon. Jap. 
3, longer than the style, plumose. Caryopsis oblong, often sliallowly sulcate in front, shortly exserted from the glume and palea, free.

Shrubby. Rhizome hypogreous, long-creeping, rooting, with many nodes. Culm erect or ascending, terminating the rhizome or brauching from it, slender, sheating at first, smooth, fistulose, with many nodes, branched; branches one to a node. Leaves broad, often large, sharply pointed, palmately arranged towards the summit of branchlets, persistent, coriaceous or chartaceous, with a short petiole which is articulated with the sheath ; midrib prominent beneath ; veins many; venules very finely tessellate. Inflorescence loosely racemosopraniculate; peduncle lateral, 1 to several or sometimes many to a culm lisually exceeding the leaves, erect, sheathing, leafless (but rirely leafy in abnormity). Spicule pedicellate, often tinged with purple.

We shall now proceed to show how our attempt may be justified.

\section{External Forms.}

When we compare carefully the flural characters of the above named species with those of Bambusa, as given in Bentham and Hooker's Genera Plantarum Vol. III. or Gamble's Bambusea Indica, we shall soon find differences of no small importance. These species are distinguished from genuine Bambusa especially by the long peduncled small inflorescence which is usually loosely pedicellate and recemose or panicled (Fig. 7), and also by the entirely glabrous ovary. The stigmatic lobes are always 3 (Figs. 6 and 11). In these points they agree rather with Arundinaria, but differ sharply from it in the number of stamens. Also in the habitus of culms and leaves, these shrubby bamboos deviate considerably from Bambusa, so that the authors who have examined only sterile specimens have referred them frequently to Arundinaria, as may be seen from the list of synonyms giren below. Moreover the rhizomes of genuine Bambusa-species have very short thronged internodes and run never horizontally, but often bending themselves upwards. Consequently their aerial shouts form very thick stocks, so that they were called by Rivière "Bambous a touffe cespitense." But all the indigenous 'Bambusa'-species are provided with very long creeping' rhizomes with considerably elongated internodes (Fig. 1), closely resembling those of Arundinaria and Phyllostachys, i.e. "Bambous a touffe très

1) A. et C. Rivière, Les lambous. Vegetation, culture et multiplication. 1878, p. 62, p. 183. 
tracante" Rivière's." We shall not, however, continue longer the less fruitful discussion of external characters, but turn to examine the anatomical structure.

\section{Interinal Structure.}

It is hardly necessary to mention that the anatomical method may render a useful service to the classification especially by such a group as Bambusea, where we encounter a great deal of difficulties in the way of classifying merely accorling to external characters. Yet it must be borne in mind that we must be very careful to distinguish among the anatomical characters the physiological ones, which are usually constant only to a species, and the phyletic ones, which are available as indications of relationship of the members belonging to certain gentera or tribes.") From this point of view the structural variations of the rhizomes,") or more exactly the different modes of arrangement of the mechanical tissues in the rhizomes seem to be the characters belonging to the former category; for instance we behold amongst the genus Phyllostachys that the thick stout rhizomes of P. mitis, P. bambusoides, etc., are devoid of any other mechanical elements except the bundle sheaths, while the slender rhizomes of $P$. Kumasasa require, as they do, the development of a complete subcortical sclerenchyma-ring to strengthen its firmness against bending. The anatomical structure of the culms and leaves affords, on the whole, so uniform an appearance throughout the representatives of several genera and subtribes, that it secms very difficult to secure any salient feature available for the purpose of classification. On the contrary we find just in the root-structure a valuable means in this respect.

The peculiar structure of the roots of somo bambio-plants has already been pointed out by $\mathrm{Ross}$, whose observations we are now able to confirm and to extend to several representatives of the Arundinariea, Eubambusese and Dendrocalimere. As fir as our present knowleilge reaches, the peculiar root-structure, i.c., the presence of internal xylem- and phloem-strands in the axial cylinder seems to furnish, amongst the monocotyledons, mostly the

1) $\mathrm{Riv}$ iè re, loc. cit.

2) Solereder, Systematische Anatomie d. Dicotyledonen. 1899. p. 7.

3) K. Sh i bat a, Beiträge z. Wichstumsgeschichte d. Bamburgew ̈̈chse. Jour. Coll. Sc. Imp. Univ. Tokyo, Vol. XIII, pt. 3, p. 43.5.

4) Ross, Beitrïge z. Anatomie abnormer Monocotylenwurzeln. Ber. d. D. Bot. Gésells. Bd. I, p. 336 . 
family characters, as is the case with the Palmea,, ${ }^{1}$ Cyclanthacese, Pandanacere, Musacex, ${ }^{2)}$ etc., cases quite analogous to the behavior of intrixylar phloems in some dicotyledons. ${ }^{3)}$ So we are justified to a certain extent to look upon the peculiar root-structure as one of the most important anatomical characters indicating the special position of th.e Bambusea among the Graminee. Moreover we have confirmed the presence of a complete uninterrupted pericambium in the root of every species examined. ${ }^{+}$By all means, the root must be regarded as preserving no:t of the important phyletic characters of the Bambusea. Then we may ank whether the root-structure can be applied as a standard of classification among the bamboo-tribe itself? We may answer this question in a positive sense. In fact we are able to distinguish two quite different modes of construction of the roots among the bamboo-plants examined by us; one presented by the species belonging to the genuine Bambusa and to Dendiocalamus, and the other by Arundinaria and Phyllostachys. It will be convenient to consider the cortex and axial cylinder separately.

The cortex of the former type is briefly characterised by the persisting epidermis, lignified but never thickened subepidermal cell-layer and a few lajers of peripheral sclerenchymatic cells, which are sharply marked off by the thin-walled cortical parenchyma. The latter is divided into two portions, the outer of which consists of large polygonal cells, and the inner of small cells, regularly arranged in riadial and concentric rows. 'The thickness of the inner layer is always a few times greater than that of the outer one. Lastly the endodermic cells are uniformly thickened in their walls, bringing about the formation of the so-called $\mathrm{O}$-sheath. The cells of one or two innermost layers of the cortical parenchyma bears on their inner walls irregularly shaped protuberances, raising themselves into the cell-lumina and consisting of almost pure cellulose. This structure may perhaps be regarded as the mechanical support of the cells against the radial pressure. Westermaie ${ }^{5)}$ has attributed a similar function to the conical processes in the

1) Reinhardt, Das leitende Gewebe einiger anomal gabanten Monocotylenwurzin. Jahrb. f. wiss. Bot. Bd. XVI, p. 336.

Gillain, Anatomie d. Pahnen- und Pandanacenwurzeln. Bot. Centralls. Bil. LXXXVII, 1900 , No. 37.

2) Ross, loc. cit.

3) Solereder, Systematische Anatomie d. Dicotyledonen, p. 9i1.

4) According to Van Tieghem (Ann. d. Sa. nat., 5e Serie t. XIII), this is not the case with most of other graminaceous plants.

5) Westermaier, Ueber Bau und Function des pll. Hautsystems. Jahrb. f. wiss. Bot. Bd. XIV, p. 64 . 
epidermal cells of Epilobium and some cyperaceous plants and in the endodermic cells of $\Lambda$ ndropogonea.

The above stated construction-type is to be met with invariably in all the examined species of genuine Bamlusch, for examples, $B$. vulgaris, B. nana, B. stenoslachya, B. Oldhami and some undetermined species from Formosa. We learn from the figures by Ross ${ }^{2}$ that $B$. arundinacea is also provided with an $\mathrm{O}$-she a th. Schwen dener ${ }^{33}$ has already enlisted Bambusa among the plants provided with O-shaped endodermic cells.

As far as our own observations are concerned, ${ }^{4)}$ the cortex of the roots of the species of Arundinaria and Phyllostachys shows a type of construction quite different from the one described alove. The figures 16 and 17 (Pl. I.) may serve as illustrations. We notice here that hypodermal cells have extruordinarily thickened outer walls, and thus replace the epidermis in its functions, the latter being destroyed very early and falling off. The peripheral sclerenchyma-layer of varying thickness passes over gradually to the cortical parenchyma. The outer layer of the cortical parenchyma is always thicker than the inner, which is traversed by a number of radially arranged air-lacuna. Again the endodermic cells manifest a quite different mode of thickening; the apposition of new material occuring only on the inner and radial walls, resulting in the formation of the so-called C-sheath. Schwendener ${ }^{\text {5) }}$ has also stated that Arundinaria possesses a C-sheath. In Arundinaria quadrangularis, Phyllostaclyys Kumasasa, etc., the innermost cell-layer of cortical parenchyma may be regarded as a "Verstïrungsring", in Schwendener's sense, its inner walls being much thickened and lignified.

As to the structure of the axial cylinder it is here to be noted that in the roots of Arundinaria-type the number of internal phloem-strinds amounts usually to one half that of the peripheral strands, while in those of Bamlusa-type both strands are almost equal in number. ${ }^{6)}$ Besides, the furm of the internal solitary sieve tubes of the latter is very characteristic, showing in cross-sections regular oval outlines.

1) Klinge, Vergl. Unt. üb. Gramineen- u. Cyperaceenwurzeln. (Abstract.)

2) Ross, loc. cit.

3) Schwendener, Schutzicheide u. ihre Verstïrkungen. Gesammelte Bot. Mittheilungen. B.I. II, p. 128 .

4) K. Sh ib ata, Beitr. z. Wachstumsgeschichte d. Bambusgewächse. Jour. Sc. Coll. Imp. Univ. Tokyo, Vol. XIII, pt. 3, p. 444, 495 .

5) Schwendener, loc. cit. p. 128.

6) K. Shibata, luc. cit. p. 447. 
We sce from the foregoing that two utterly different structural types occur in the root, in no way as parallel formations within the same genus, but as being respectively common to all the members not only of a genus, bat even of allied genera, such as Arundinaria and Phyllostacliys on the one hand, and Bambusa and Dendrocalamus on the other. At any rate they are buth equally rational constructions viewed from the physiological standpoint and may be regarded as the phyletic characters indicating the natural relationship existing between allied genera.

Now we will return to the proper subject of our present discussion and cxamine the root-structure of the indigenous species formerly included in the genus Bambusa, such as B. senanensis, B. Veitchii, B. palmata, B. borealis, B. nipponica, B. remosa, B. clartacea, etc. The roots of all these species possess, however, no feature common with the Bambusa-type, but they are, on the contrary, constructed in an exactly similar manner with those of Arundinariese, so that it seems to us quite superfluous to enter into their detailed descriptions. The comparison of Figs 18 and 19 (I'l. I.) (BamLusa stenostachya) with Figs. 16 and 17. (Sasa ('Bamlusa') borealis) will make the difference existing between them at once manifest. It may be here noted in passing that the embryonal roots ("Keimwurzel") of the seedlings of Bambusa nana," Arundinaria Simoni and Sasa ("Bambusa') borealis repeat respectively in every detail the construction-types of the adult plants, and consequently no room is left for doulting that they are constant hereditary characters. It should also be added that the characteristic parenchyma-lamellke inserted trunsversely in the bundle-sheaths, which are never absent in the culms of Bambusa and Dendrocalamus, are hardly discernible in those of the members of our new genus.

It is evident that the plants which present such a striking deviation in the important phyletic characters, as seen from the above discussion, can no longer be brought together under the same genus, and it follows necessarily that the above named indigenous 'Bambusa'-species should he rationally separated from Bambusa, while the possession of six stamens suffices to characterise a distinct genus.

\section{Species and Distribution.}

'The above considerations relating to exomorphic as well as to endo-

1) We are indebted to Dr. K. Fujii for kindly giving us some seeds of this species.

2) Schwendener, Das mechanische Princip in anat. Ban d. Monocotylen. p. 65; K. Shibat a, loc. cit. p. 441. 
morphic characters appear to us to justify the establishment of a new genus, and we shall give in the following lines an enumeration of all the known species referall'e to this genus, together with their synonyms, distributions, etc,

Šasa borealis nom. nov.

Bambusa borecilis Hack. in Bull. Herb. Boiss VIT, 1899, p. 720.

Arundinaria borecalis Makino Bambusacese Japonicie in Bot. Mag., Tokyo, XIV, 1900, p. 20.

Bambusa purpurascens Makino in Dascription des Produits forestiers envoyés à l'Exposition univer.elle de 1900 à Paris par le Ministère de l'Agriculture et du Commerce; Id. in Bot. Mag., Tokyo, XIV, p. 62.

? Arundinaria purpurescens Hack. l.c. p. 716.

Bambusa senanensis Hort.; F.-Mitf. Bamb. Gard. p. 78 (sp. post.); F. Satow Cult. Bamb. Jap. in Trans. Asiat. Soc. Jap. XXVII, 3, p. 65, cum icon.

Nom. Jar. Suzu-dake.

Distrib. Throughout Japan.

Sasa ramosa nom. nov.

Bambusa ramosa Makino in Descript. d. Prod. forest. env. à l'Exposit. miv. 1. 1900 i Paris; Id. in Bot. Mag., Tokyo, XIV, p. 62.

Aruntinaria ramosa Makino Bamb. .Jap. in Bot. Mag., Tokyo, XIV, p. 22.

Non. Jap. Adruma-zilsa.

Distris. Middle and northern Japin.

Sasa nipponica nom. nov.

Bambusa nipponica Makino in Bot. Mag., Tokjo, IX, 1895, p. 72; Id. in Descript. d. Prod. forest. env. à l'Exposit. univ. d. 1900 à Paris; Id. in Bot. Mag., Tokso, XIV, p. 62.

Arundinarie nipponica Makino Bamb. Jap. in Bot. Mag., Tokyo, $\mathrm{XIV}$, p. 24.

Arundinaria dimorpla Hack. in litt. 1899 (nomen), ex J. Matsumura in Herb. Sc. Coll. Imp. Univ., Tokyo.

Noм. Јаг. Miyalo-zasa.

DisTrib. Throughont Japan. 
Sasa albo-marginata nom. nov.

Phyllostachys bambusoides ß. albo-marginata Miq. Prol. Fl. Jap. p. 172 ; Ill. Catal. Mus. Bot. Lugd.-Bat., Fl. Jap. p. 114.

Bambusa senanensis $r$ albo-marginata Fr. et Sav. Enum. Pl. Jap. II, p. 606 ; Hack. in Bull. Herb. Boiss. VII, 1899, p. 720.

Bambusa albo-marginata Makino in Descript. d. Prod. forest. env. ì l'Exposit. univ. d. 1900 à Paris ; Id. in Bot. Mag., Tokyo, XIV, p. 62.

Arundidaria albo-marginala Makino Bamb. Jap. in Bot. Mag., Tokyo, XIV, p. 30.

Bambusa Veitchii Carrière in Revue Hort. 1889, 1. 90 ; Wats. in Gard. Chron. 3rd Ser. III, 1888, p. 332 ; Kew Bulletin, 1899, p. 79, excl. syn.; E. Satow Cult. Bamb. Jap. in Truns. Asiat. Soc. Jap. XXVII, 3, p. 63, cum icon.

Arundinaria Veitchii N. B. Brown in Gard. Chron. 3rd Ser. V, 1889, p. 521, excl. syn. nonnul.; Bean in Gard. Chron. 3rd Ser. XV, 1894, pp. 209, 301 ; F.-Mitf. Bamb. Garl. 1. 77, cum tab.

Bambusa tessellata Hort. ex Bean l.c. pp. 209, 368, non Munro.

Jambos Kumasasa ß. fuivinokumsasa sive Jakivasasa Sieb. Syn. Pl. Oeconom. Jap. p. 6.

Nom. JAr. Kuma-sasa, Yaliba-zasa.

Distrib. Nearly throughout Japan.

forma minor.

Bambusa albo-marginata forma minor Makino in Descript. d. Prod. forest. env. à l'Exposit. univ. d. 1900 ì Paris.

Arundinaria albo-marginata forma minor Makino Bamb. Jap. in Bot. Mag., Tokyo, XIV, p. 32.

Nom. JAP. Ko-Tumasasa.

Distrib. Cultivated.

Sasa paniculata nom. nov.

Arundinaria liurilensis $\%$ paniculata Fr. Schm. Fl. Sachal. p. 198.

Bambusa paniculata Makino in 1)escript d. Prod. forest. env. à l'Exposit univ. d. 1900 à Paris ; Id. in Bot. Mag., 'Tokyo, XIV, p. 62, non Willd. p. 50 .

Arundinaria paniculata Makino Bamb. Jap. in Bot. Mag., Tokyo, XIV,

Bambusa senanensis Fr. et Sav. Enum. Pl. Jap. II, pp. 182, 606 ; Hack. in Bull. Herb. Boiss. VII, p. 719. 
Bambusc palmata Marliac; Bean in Gard. Chron. 3rl. Ser. XV, 1894, p. 167, fig. 18, excl. syn., et pp. 209, 368 ; F-Mitf. Bamb. Gard. p. 79 cum tab.; Makino in Descript. d. Prod. forest. env. à l'Exposit. univ. d. 1900 à Paris; Id. in Bot. Bot. Mag., Tokyo, XIV, p. 61.

Arundinarica palmata Bean in Gard. Chron. 3rd Ser. XV, p. 238.

? Bambusa reticulata forma major Rupr. Bamb. in Mém. Acad. Pétersb. Sér. VI, 5, p. 148.

? Bambusa reticulata var. macrophylla Rupr.

Bambusa tessellata Makino in Bot. Mag., Tokyo, IX, 189.5, p. 73, non Munro.

Nom. JAP. Nemagari-dake, Chimaki-rasa.

Distrims. Throughout Japan.

\section{forma nebulosa.}

Bambusc palmata forma nebulosa Makino in Descript. d. Prod. forest. env. à l'Exposit. d. 1900 à Paris ; Id. in Bot. Mag., Tokyo, XIV. p. 61.

Arunclinaria palmata forma nebulosa Makino Bamb. Jap. in Bot. Mag., Tokyo, XIV, p. 52.

Bambusa metallica F.-Mitf. ex Satow Cult. Bamb. Jap. in Trans. Asiat. Soc. Jap. XXVII, 3, p. 78.

Tora-fu-dake Satow 1. c. p. 127, cum icon.

Nom. Jap. Shakotan-chitu, Shakohan-chitu.

Distris. Throughout Japan.

var. stenantha.

Bambusa stenantha Makino in Descript. d. Prod. forest. env. ì l'Exposit. Univ. d. 1900 à Paris ; Id. in Bot. Mag., Tokyo, XIV, p. 62.

Arundinaria paniculata var. stcnantla Makino Bamb. Jap. in Bot. Mag., 'Tokjo, XIV, p. 52.

Noм. JАr. Me-Timai-zasa.

Distuis. Northern Japan.

var. nana.

Arundinaria nana Hack. in litt. (nomen) ex J. Matsumura in Herb. Sc. Coll. Imp. Univ. 'Tokyo.

Arundinaria paniculate var. nana Makino Bamb. Jap. in Bot. Mag., Tokyo, XIV, p. 54.

Nом. ЈАг. Miyama-suzu.

Distrib. Middle and northern Japan. 
Sasa chartacea nom. nov.

Arundinaria chertacea Makino Bamb. Jap. in Bot. Mag., Tokyo, XIV, P. 55 .

Nom. Jar. Ülumazasa.

Distrib. Middle Japan.

Sasa kurilensis nom. nov.

Arundinarica Furilensis Rupr. in Bull. Phys.-Math. P'étersb. VIII, p. 121 ; Ledeb. Fl. Ross. IV. p. 395 ; Steud. Syn. Pl. Glum. I. Gram. p. 335; Munro Monogr. Bımb. in Trans. Linn. Soc. XXVI, p. 17 ; Fr. Schmidt Fl. Sachal p. 198 (var. c. genuina); Makino Bamb. Jap. in Bot. Mag., Tokyo, XIV, p. 67.

Bambusa kurilensis Miyabe Fl. Kuril. Isl. in Mem. Bost. Soc. Nat. Ilist. IV, p. 271 ; Hack. in Bull. Herb. Boiss. VII, p. 719.

Arundo Donax Georgi, non Linn.

Nom. JAP. Chishima-zasa.

Distrib. North Japan.

\section{Sasa tessellata nom. nov}

Bambusa tessellata Munro Monogr. Bamb. in Trans. Linn. Soc. XXVI, 1. 110 ; N.E. Brown in Gard. Chron. 3rd Ser. V, 1889, p. 521 ; Nichols. Illustr. Dict. Garden. I, p. 156 ; Bean in Gard. Chron. 3rd Ser. XV, pp. 167, 209, 368, fig. 17; F.-Mitf. Bamb. Gard. p. 82 ; E. Sitow Cult. Bamb. Jap. in Trans. Asiat. Soc. Jap. XXVII, 3, p. 122.

Arundinaria tessellata Bean l. c. p. 238, non Munro.

Bambusa Ragamowsli Wheeler in Gard. Chron. VI, 1876, p. 8t7, et VII, 1877, p. 50 ; IF.-Mitf. l. c.; Nichols. 1. c.

Arundo liagamowski Lambert. MSS. ex Wheeler l.c. VI, 1876, 1. 847 .

Aiundinaria Muximowicaii Hort. ex F.-Mitf. 1. c. p. 101.

Distris. China.

We see from the above enumeration that the present genus contains no less than eight species with a number of varieties and forms. Most of the species hitherto known are confined to Japan. Sasu kurilensis is found, as the most northern representative even of the whole bamboo-tribe, in Ourup, one of the Kurile islands, in about $46^{\circ}$ N.L.," and towards the

1) K. Miy a be, Flora of Kurile Is'ands. Mem. Bost. Soc Nat. Hist. IV, p. 271. (We have not yet examined the root-structure of this species, but several observations lead us to bring it under the genus Susil). 
south Sasa nipponica and Sasa paniculata extend to Kiusin. The whole genus flourishes most luxuriantly in middle Japan, contributing greatly to the characteristic physiognomy of our mountain vegetation. Here we have another notable example of the restricted distribution, which characterises most of the bambuseous genera, ${ }^{1)}$ and we have good reason to assume that the present genus is a natural monophyletic group,") whose "Entstehungscentrum" lie probably also within its present domain. Yet it is quite possible that the adjoining districts, such as Corea, northern China, etc. may shelter some unknown members of the genus; and the addition of new species may perhaps be expected from these regions.

\section{Systematic Position of the Genus Sasa and Remarios on the Classification of the Banbuses.}

We may perhaps add a few words on the systematic position of our new genus. Though our present knowledge of the anatomical structure of several exotic forms remains incomplete, we may still with good renson draw ip the following diagram :3)

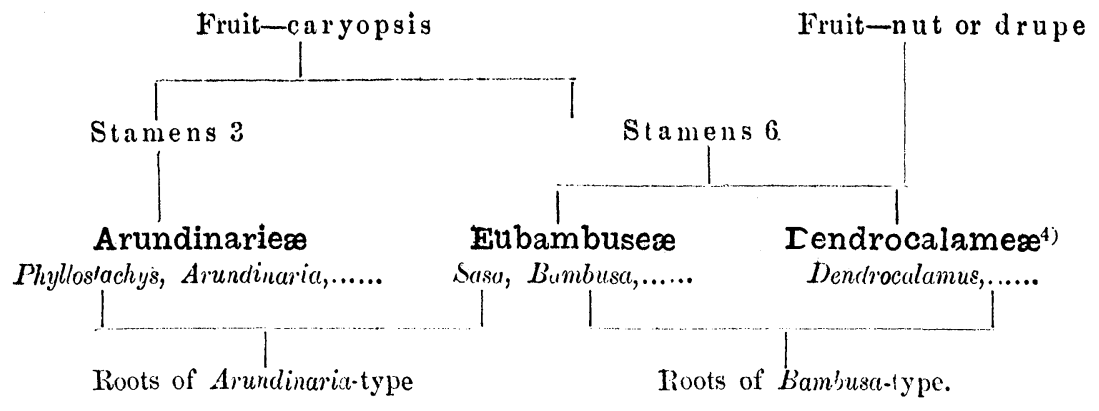

1) Schröter, Der Bambus und seine Berleutung als Nutypflanze. Basel. 1885, p. 18 ; Munro, Monogr. Bamb. p. 4.

2) Engle r, Entwicklungsgeschichte der extratropischen Florengebicte. Theil II, p. 322.

3) We were nnable to examine representatives of the subtribe Melocannex.

4) Dendrocalamee, which is in many respects closely allied to the Eubambuser, scems to be of a more recent descent, to judge from the foim of its fruit, which deviates from that of the whole remaining members of the Graminex, as also from its restricted distribution in the tropical region of the eastern hemisphere. 
The first thing to ba noticel is the non-coincidence of the range of variations of the anatomical and floral characters. When we put our new genus Sasa under the subtribe Eubambusere for the sake of its 6 stamens, then the border-line drawn according to the difference of the root-structure passes through between Sasa and Bambusa, cutting Eubambusese into two sections. Schwendener has pointed out a quite analogous case in his wellknown paper on the mestom-sheath of the graminaceous leaves.1) The grouping of the tribes belonging to the Graminew into two subdivisions according to the mestom-sheath brings about the border-line passing through the tribe Panicer; a part of the tribe together with Maydere and Andropogonete being sharply distinguished from the whole mass of the remaining members of the grass-family by the absence of the mestom-sheath. Schwendener has yet appropriately never regarded Panicea as an unnatural group, because the multitude of other anatomical characters proves itself strongly in favor of the homogeneity of the tribe.") What is then the case with Eubambusese? It seems to us, however, decidedly unnatural to put Sasa under Eubumbusese, for not only the difference of the rootstructure, but the total sum of internal and external characters tends evidently to outweigh the mere agreement in the number of stamens, which is moreover not always free from variation. It must then be more reasonable to exclude Sasa from Eubambusese and to introduce it into Arundinariex. It is a noteworthy fact that Sasa borealis is very closely allied in its vegetative characters to Arundinaria japonica, ${ }^{3)}$ an endemic species of that phylogenetically old genus. The relationship of the two is made more intimate by the circumstance that $A$. japonica has at times a greater number of stamens than 3, and we have good reason to seek in this very point the close connection between Sasa and Arundinaria. We have schematised, after careful observations of both floral and vegetative characters, the relittionship among the species of our new genus in the following manner.

1) Schwendener, Die Mestomscheide d. Gramineenblätter. Gesammelte Bot. Mitteilungen. Bd. II, p. 190.

2) Schwendener, loc. cit. p. 182.

3) Makino, Bambusaceæ Japonicæ. The Botanical Magazine, Tokyo, Vol. XIV, p. 21. Arundinaria japonica $=$ "Ya-dake." 


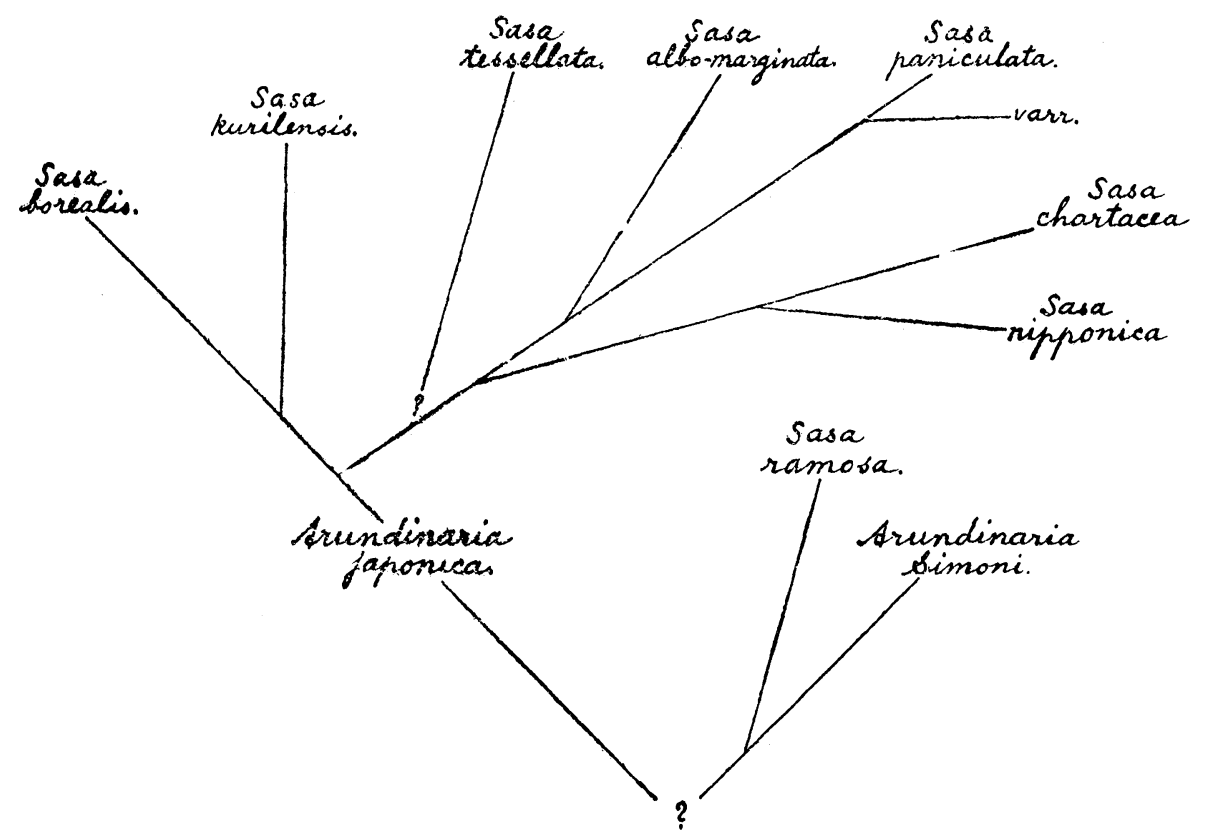

Remark-To avoid mismonderstanding, it is to be noted that the genus Susa may not necessarily be regarded as a direct descendant of Arundineria japonica.

Sasaramosa, which we inchide provisionally in our new genus, resembles, however, Arundinaria Simoni in its floral characters, and his often less stamens than 6.1) Further study will decide whether it represents the type of a distinct genus or not. With the erection of our new genus the distinction between the Arundinariese and Eubambuse $e$ in the older sense ${ }^{2}$ ) becomes naturally less sharp, and we believe that the rootstructure, as a definite and easily accessible taxonomic character, will serve hereafter, along with floral characters, the purpose of a rational classification of the Bambusca.

In conclusion, we wish to express our sincere thanks to Professor J. Matsumura, and also to Professor M. Miyoshi, for their kind advice and helpful suggestion.

Botanicat. INstitute,

IMPETIAL UNIVERSTTY OF TOKYO.

1) Makino, loc. cil. p. 2:3. Arundincerice Simoni="Me-take."

2) Bentham et Hooker, Genera Plantarum. Vol. III, p. 1094; II ackel, Bambusere. Engler's Dic natürliche PHam\%enfamilien. II, 2, p. S9. 


\section{Explanation of Figures in Pe. $T$.}

Sasa albo-marginata Malkino et Shibata.

Fig. 1. Plant in flower, with a portion of the long creeping rhizome. $\times \frac{1}{3}$.

Fig. 2. A portion of the culm with a branch.

Fig. 3. A detatched spikelet. $a, b$ empty glumes. Nat. size.

Fig. 4. A separate flower, showing 6 stamens. Enlarged.

Fig. 5. Lodicule. Enlarged.

Fig. 6. A pistil. Enlarged.

\section{Sasa borealis Malino et Shibata,}

Fig. 7. An inflorescence. $\times \frac{3}{2}$.

Fig. 8. A spikelet. $a, b$ empty glumes, Slightly enlarged,

lig. 9. A separate flower, Enlarged,

Fig. 10. Iodiculie. Eullitrged,

Fig. 11. A pistil.

Fig. 12. Floral diagram.

Fig. 13. Caryopsis. Nat. size.

Fig. 14. Diito. Enlarged.

Fig. 15. Transverse section of the peripheral region of the root-cortex: hypp. hypodermal cells with thickenel onter walls; sct. a portion of the peripheral selerenchymatic layer. $\times 3500$.

Fig. 16. Transverse section of the root, showing the C-formed endodermic cells (end.): vers. innermost cell-layer of the root-cortex, forming "Verstïrkungsring"; per. pericambium. $\times 350$.

Fig. 17. Endodermis of the root of Sasa paniculata Makino et Shibata in earlier stage of thickening : $R$. cortical parenchyma ; $c n d$. endodermis ; per. pericambium. $\times$ ca. 400.

Bambusa slenostachya Hack.

Fig. 18. Transverse section of the root, showing the persistent epidermis (ep.) and unthickened hyporlermis (hyp.); scl. sclerenchymatic layer; li. cortical parenchyma; $h$ root hair. $\times$ ca. 350 .

Fig. 19. 'Transverse section of the root, showing the O-formed endodermis (end.): $R$. innermost layer of the cortical parenchyma; per. pericambium. $\times$ ca. 350 . 